\title{
Unusual presentation in cow's milk protein allergy
}

\author{
Ana Araújo Carvalho \\ (ㄷ) , Joana Faustino \\ (1) ,' Sofia Bota (10, ${ }^{2}$ Sara Tavares Ferreira ${ }^{1}$
}

'Department of Pediatrics, Hospital Dona Estefânia, Lisboa, Portugal

${ }^{2}$ Pediatric Gastroenterology Unit, Hospital Dona Estefania, Lisboa, Portugal

Correspondence to Dr Ana Araújo Carvalho; anacarvalho.fcm@gmail.com

Accepted 10 June 2021

\section{DESCRIPTION}

Cow's protein milk allergy (CPMA) is the most common food allergy in infants $(2 \%-3 \%$ of the infant population), typically occurring in the first 6 months of life. ${ }^{12}$ Family history of atopy, prematurity or previous use of antibiotics are possible risk factors for CPMA. ${ }^{3}$ Common non-immunoglobulin E-mediated symptoms include vomiting, regurgitation, diarrhoea, rectal bleeding and irritability in an otherwise healthy infant. ${ }^{24}$

A 34-day-old male infant, previously breast fed, with a clinical background of late prematurity ( 35 weeks), was small for gestational age, requiring hospitalisation to achieve feeding autonomy, and at 21 days old due to urinary tract infection. He had a 5-day history of mucus, bloody diarrhoea, irritability and frequent regurgitation, which started 1 day after consuming an infant formula and did not improve even after consuming an extensively hydrolysed (EH) formula for 2 days. General examination was unremarkable, including the presence of bowel sounds and depressible abdomen without visible collateral circulation. Sepsis screening on blood tests was negative. Stool culture was negative for Salmonella, Shigella and Campylobacter, as was the antigen detection of rotavirus, adenovirus, astrovirus and Norwalk. Abdominal radiography

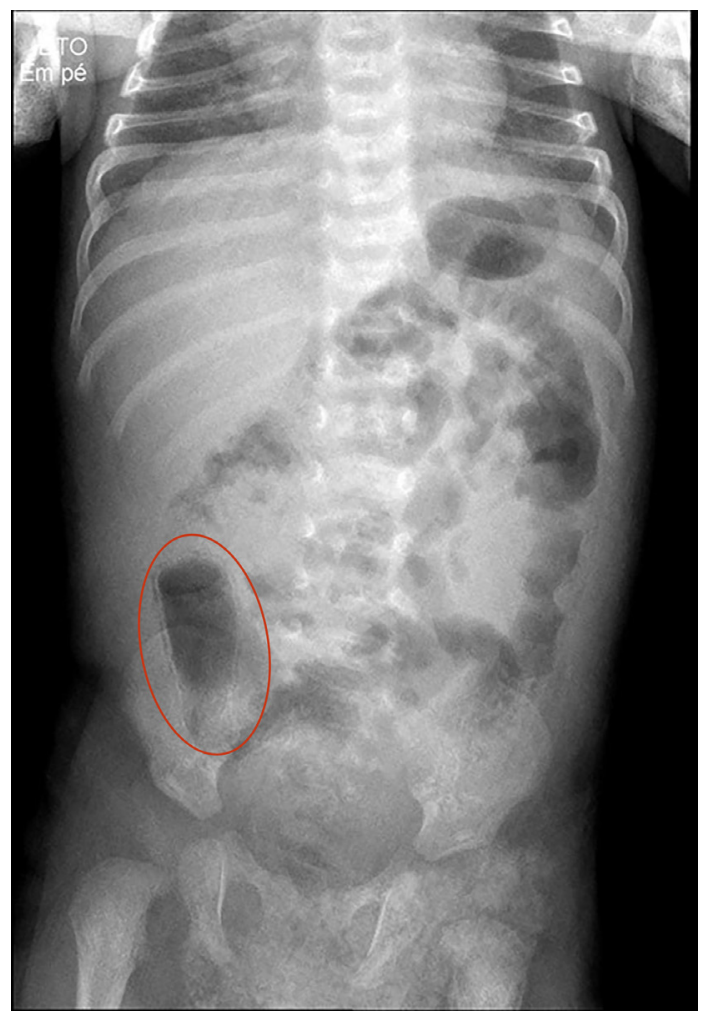

Figure 1 Pneumatosis intestinalis. (figure 1) revealed pneumatosis intestinalis (PI), and abdominal ultrasound revealed aeroportia. Empirical, intravenous antibiotic therapy (cefotaxime, gentamicin and metronidazole) was initiated to treat gram-negative, gram-positive and anaerobic bacteria. He was on total parenteral nutrition exclusively for 3 days. After 48 hours, the mucus and bloody diarrhoea stopped, and findings of abdominal radiography and ultrasound were normal. EH was slowly reintroduced; however, the infant had frequent episodes of regurgitation with facial congestion and cyanosis, which improved after switching to a thickened amino acid-based formula (AAF) and starting esomeprazole. $\mathrm{He}$ was discharged after 10 days of antibiotic therapy, with favourable outcomes. Through his first year, attempts to reintroduce cow's milk protein (CMP) led to resumption of symptomatic oesophageal reflux and the need to continue with AAF, resulting in a failure to thrive.

In term or near-term infants, CPMA and necrotising enterocolitis (NEC) may be difficult to differentiate based on the initial symptoms. ${ }^{3}$ In this case, the presence of bloody stools and PI suggested NEC, ${ }^{13}$ and it was treated initially. However, less severe disease processes, such as CPMA, can also cause PI. ${ }^{5}$ We made this diagnosis based on the following findings: (1) gastrointestinal symptoms started after 1 month of age, and typically, NEC occurs within the first week after birth ${ }^{5} ;(2)$ prematurity is a reported risk factor for $\mathrm{CPMA}^{1}$; (3) NEC with PI indicates Modified Bell's Stage II, an uncommon finding in an infant appearing healthy and having normal laboratory findings and (4) clinical evolution, with continuous need for $\mathrm{CMP}$ avoidance and failure to thrive, matched with CPMA.

To avoid unnecessary interventions, benign causes of PI should be considered if severe systemic disease is not obvious. ${ }^{5}$ In CPMA, disease presentation and symptom severity are diverse, ${ }^{2}$ but they

\section{Learning points}

- Pneumatosis intestinalis is a frequent finding of necrotising enterocolitis (NEC), but it can occur in other, more frequent conditions, such as severe cow's protein milk allergy (CPMA), which paediatricians should be aware of.

- Non-immunoglobulin E-mediated CPMA diagnosis and management may be challenging.

- Not all infants with CPMA respond to the extensively hydrolysed formula, so an amino acid-based formula should be tested in these cases. 
usually have good prognosis after removing CMP exposure. ${ }^{4}$ Despite that most infants with CPMA are able to tolerate the $\mathrm{EH}$ formula, almost $10 \%$ do not and require AAF, especially if presenting with severe enteropathy, like in this case. ${ }^{2}$

Contributors $A A C$ and JF were responsible for patient management during hospital admission, monitoring the clinical evolution everyday and discussing the clinical evolution with gastroenterology. We have done the literature review and wrote this article. SB, a doctor dedicated to paediatric gastroenterology, reviewed the article and continued the follow-up of the patient in subsequent appointments. STF reviewed the article and was responsible for the decisions made about this patient during the hospital stay.

Funding The authors have not declared a specific grant for this research from any funding agency in the public, commercial or not-for-profit sectors.

Competing interests None declared.

Patient consent for publication Not required.
Provenance and peer review Not commissioned; externally peer reviewed.

\section{ORCID iDs}

Ana Araújo Carvalho http://orcid.org/0000-0002-0280-047X

Joana Faustino http://orcid.org/0000-0003-4015-5624

Sofia Bota http://orcid.org/0000-0003-4776-1053

\section{REFERENCES}

1 Liu H, Turner TWS. Allergic colitis with Pneumatosis intestinalis in an infant. Pediatr Emerg Care 2018;34:e14-15.

2 Koletzko S, Niggemann B, Arato A, et al. Diagnostic approach and management of cow's-milk protein allergy in infants and children: ESPGHAN Gi Committee practical guidelines. J Pediatr Gastroenterol Nutr 2012:55:221-9.

3 Cordova J, Sriram S, Patton T, et al. Manifestations of cow's-milk protein intolerance in preterm infants. J Pediatr Gastroenterol Nutr 2016;62:140-4.

4 Srinivasan P, Brandler M, D'Souza A, et al. Allergic enterocolitis presenting as recurrent necrotizing enterocolitis in preterm neonates. J Perinatol 2010;30:431-3.

5 Siddique Z, Thibodeau R, Jafroodifar A, et al. Pediatric milk protein allergy causing hepatic portal venous gas: case report. Radiol Case Rep 2021;16:246-9.

Copyright 2021 BMJ Publishing Group. All rights reserved. For permission to reuse any of this content visit

https://www.bmj.com/company/products-services/rights-and-licensing/permissions/

BMJ Case Report Fellows may re-use this article for personal use and teaching without any further permission.

Become a Fellow of BMJ Case Reports today and you can:

Submit as many cases as you like

Enjoy fast sympathetic peer review and rapid publication of accepted articles

- Access all the published articles

Re-use any of the published material for personal use and teaching without further permission

Customer Service

If you have any further queries about your subscription, please contact our customer services team on +44 (0) 2071111105 or via email at support@bmj.com.

Visit casereports.bmj.com for more articles like this and to become a Fellow 